\title{
Housekeeping Proteins in Meat Quality Research: Are They Reliable Markers for Internal Controls in Western Blot? A Mini Review
}

\author{
Chaoyu Zhai ${ }^{1}$, Elisabeth Huff-Lonergan ${ }^{2}$, Steven M. Lonergan ${ }^{2}$, and Mahesh N. Nair ${ }^{1 *}$ \\ ${ }^{1}$ Department of Animal Sciences, Colorado State University, Fort Collins, CO 80523, USA \\ ${ }^{2}$ Department of Animal Science, lowa State University, Ames, IA 50011, USA \\ *Corresponding author. Email: mnair@colostate.edu (Mahesh N. Nair)
}

\begin{abstract}
Advancements in technology and analytical methods enable researchers to explore the biochemical events that cause variation in meat quality. Among those, western blot techniques have been successfully used in identifying and quantifying the key proteins that have critical functions in the development of meat quality. Housekeeping proteins, like $\beta$-actin, glyceraldehyde 3-phosphate dehydrogenase (GAPDH), and tubulins are often used as internal controls in western blots to normalize the abundance of the protein of interest. However, there are increasing concerns about using housekeeping proteins for western blot normalization, as these proteins do not demonstrate any loading differences above the relatively small total protein loading amounts of $10 \mu \mathrm{g}$. In addition, the interaction between these housekeeping proteins and programmed cell death processes highlights the concerns about using the housekeeping protein as the internal control in meat quality research. Moreover, recent proteomic research has indicated that the abundance of some housekeeping proteins, like $\beta$-actin, GAPDH, and tubulin, can be altered by preslaughter stress, dietary supplementation, sex, slaughter method, genotype, breed, aging period, muscle type, and muscle portion. Furthermore, these housekeeping proteins could have differential expression in meat with differing color stability, tenderness, and water holding capacity. Therefore, this review aims to examine the realities of using housekeeping proteins as the loading control in meat quality research and introduce some alternative methods that can be used for western blot normalization.
\end{abstract}

Key words: postmortem muscle, $\beta$-actin, GAPDH, tubulin, western blot

Meat and Muscle Biology 6(1): 11551, 1-15 (2021)

doi:10.22175/mmb.11551

Submitted 10 October 2021

Accepted 23 November 2021

\section{Introduction}

Meat quality attributes such as color, tenderness, and juiciness are highly variable and are governed by the functionality of specific proteins present in meat. These quality attributes can significantly affect consumer purchasing and repurchasing decisions (Shackelford et al., 2001; Mancini and Hunt, 2005; Suman and Joseph, 2013; Neethling et al., 2017) and are economically significant. Inconsistencies in meat quality attributes have been extensively studied over the last couple of decades to understand the fundamental mechanisms behind these quality differences. Progress in technology and analytical methods have brought different mechanistic perspectives into meat quality research. These advancements have been used in research to help examine antemortem and postmortem factors, such as response to muscle fiber profile (Picard and Gagaoua, 2020; Matarneh et al., 2021), breeding and genetic selection (Warner et al., 2010; Berry et al., 2017), heat stress (Zaboli et al., 2019; Gonzalez-Rivas et al., 2020), oxidative stress (Bekhit et al., 2013), chilling methods (Zhang et al., 2019c), packaging methods (McMillin, 2017), aging processes (Kim et al., 2018b), antioxidant supplementation (Jiang and Xiong, 2016), and biomolecular interactions (Ramanathan et al., 2020), such as the interaction between lipid oxidation, myoglobin, and mitochondrial functionality. 
The western blot method (Towbin et al., 1979), named after the southern blot for DNA (Burnette, 1981) and northern blot for RNA (Alwine et al., 1977), is commonly used in meat quality research for detecting and (semi-)quantifying specific proteins in given samples. Extracted proteins are separated based on molecular weight through gel electrophoresis and then transferred to a membrane. Antibodies specific to the protein of interest are used to label/identify bands containing these proteins. Key proteins that have either critical functions in the development of meat quality (Liu et al., 2019; Ma and Kim, 2020; Wang et al., 2020a) or potential biomarkers of biological pathways associated with meat quality (Chen et al., 2017; Zhang et al., 2017; Cramer et al., 2018) or posttranslational modifications (Li et al., 2016; Zhang et al., 2019a; Wang et al., 2020b) have been successfully identified and quantified using western blot.

In most cases, a comparative western blot approach relies on an equal amount of protein load in each lane. Thus, a protein quantification step is usually performed before protein loading, such as the bicinchoninic acid assay (Smith et al., 1985). As there are multiple steps between protein determination and visualization of blotted proteins, several factors can lead to unequal loading of proteins at the membrane level. Many laboratories perform immunostainings of housekeeping proteins as a standard to evaluate equal loading and compensate for potential loading differences at the level of transferred proteins.

The so-called housekeeping proteins are typically constitutive proteins required to maintain basic cellular functions and are expressed in all cells of an organism regardless of the physiological conditions. Therefore, housekeeping proteins, such as $\beta$-actin, glyceraldehyde 3-phosphate dehydrogenase (GAPDH), and tubulins are often used as internal controls in western blots to normalize the abundance of the protein of interest. The housekeeping proteins are thought to be expressed consistently (at the same levels) across experiments. However, advancements in research across different fields have raised increasing concerns about using housekeeping proteins for western blot normalization (Moritz, 2017), primarily because of the inconsistent housekeeping protein expression levels observed in samples from different treatments and tissue types. The skeletal muscle from livestock species can be heterogeneous due to antemortem and postmortem factors, and postmortem aging period can further affect proteome profile by proteolysis. Nevertheless, the use of housekeeping proteins in meat science has not yet been carefully reviewed. Therefore, this review aims to examine the challenges of using housekeeping proteins as loading controls in meat quality research and to introduce some alternative methods that can be used for western blot normalization in meat science research.

\section{The Challenge of Using Housekeeping Protein as the Internal Control for Western Blot}

$\beta$-actin, GAPDH, and $\alpha$ and $\beta$ tubulins are the most popular housekeeping proteins used to normalize western blots. $\beta$-actin is one of the actin isoforms $(42 \mathrm{kDa})$ and is a highly conserved protein involved in cell motility, structure, and integrity. GAPDH is an enzyme of about $37 \mathrm{kDa}$ that catalyzes the sixth step of glycolysis, which catalyzes the conversion of glyceraldehyde 3-phosphate into 1,3-bisphosphoglycerate. Both $\alpha$ and $\beta$ tubulins are tubulin isoforms $(50 \mathrm{kDa})$, which are the principal constituents of microtubules.

A clinical study by Ferguson et al. (2005) examined the variability of $\beta$-actin and GAPDH compared to the total protein levels in different human tissues. They reported up to 4-fold abundance difference in $\beta$-actin between stomach and adrenal samples and 2.5-fold abundance difference in GAPDH between lung and spinal cord samples. Later on, another research group (Dittmer and Dittmer, 2006) examined the ability of $\beta$-actin-specific antibodies to recognize differences in protein loading. They reported that at the high total protein loads (1.88 to $7.5 \mu \mathrm{g}$ per lane) required to detect low-abundance proteins, $\beta$-actinspecific antibodies failed to distinguish differences in $\beta$-actin protein levels, indicating saturation, thus negating the ability to distinguish loading differences. The same issue was also reported in GAPDH (more than $10 \mu \mathrm{g}$ per lane) and tubulins (more than $10 \mu \mathrm{g}$ per lane) (Aldridge et al., 2008; Eaton et al., 2013; Thacker et al., 2016). These researchers demonstrated that $\beta$-actin, GAPDH, and $\alpha / \beta$-tubulins are likely saturated in most experiments when used as a loading control, as they do not reflect any loading differences above the relatively small total protein loading amount of $10 \mu \mathrm{g}$. Taylor and Posch (2014) reviewed the western blot workflows focusing on sample preparation and data analysis for quantitative western blot. They emphasized that determining the linear dynamic range of protein loading is necessary to avoid overloading highly expressed target proteins, particularly the loading controls used to normalize the data (Taylor and Posch, 2014). Moreover, 
the differential expression of these housekeeping proteins was observed in other tissues from various models (Vigelsø et al., 2014; Fortes et al., 2016; Bettencourt et al., 2020), potentially making their use unacceptable for comparisons across tissues.

In the last 2 decades, different proteomic methods, like two-dimensional polyacrylamide gel electrophoresis (2D-PAGE) (Nair et al., 2016), two-dimensional differential gel electrophoresis (2D-DIGE) (Cruzen et al., 2015), label-free mass spectrometry (Yu et al., 2017), isobaric tag for relative and absolute quantitation (iTRAQ) (Xing et al., 2017), and tandem mass tag (TMT) labeling (Li et al., 2018, Zhai et al., 2020) have been applied to investigate the differentially abundant proteins and their enriched biological pathways corresponding to meat quality. Among the highlighted biological pathways, apoptotic cell death has been targeted as one of the most critical biological events in muscle-to-meat conversion and meat quality development during postmortem aging (Laville et al., 2009; Longo et al., 2015; Ma et al., 2020; Zhai et al., 2020). Ouali et al. (2006) first described the analogies between apoptosis and postmortem changes in skeletal muscle. This hypothesis was supported by the evidence that the caspase proteolytic system, the vital executioners of apoptosis, is associated with the tenderization process in pork longissimus and lamb longissimus (Kemp et al., 2006, 2009). After both morphological observation and caspase activity measurement, Becila et al. (2010) and Cao et al. (2010) confirmed the existence of apoptotic cell death in postmortem rat and beef muscle, respectively. Later on, the relationship between apoptosis and meat quality was further verified in meat from chicken (Chen et al., 2017) beef (Wang et al., 2017), and lamb (Cramer et al., 2018).

A recent proteomic study analyzed 1,297 proteins identified in 2 previous studies that evaluated protein expression across 12 different healthy human tissues (Higdon and Kolker, 2015). These authors reported that only 34 of the 1,297 proteins had a coefficient of variation less than $30 \%$ across the 12 tissues, and only 13 of those had corresponding genes that had within tissue measurement coefficient of variation less than 20\% (Higdon and Kolker, 2015), which indicates that a dynamic range of protein expression exists even within same normal tissue. Meanwhile, an increasing number of researchers have pointed out that some housekeeping proteins, like $\beta$-actin, GAPDH, and tubulins, are involved with cell death processes. For example, $\beta$-actin is involved in the process of cell death, especially apoptosis, at both the protein and RNA levels (Naora and Naora, 1995; Guénal et al.,
1997; Li et al., 2004; Tang et al., 2006; Wang and Li, 2007; Zhao et al., 2009; Arruda et al., 2012). In addition, many studies reported that GAPDH could affect cell death or apoptosis via a variety of biological processes (Chuang and Ishitani, 1996; Ishitani et al., 1996; Ishitani and Chuang, 1996; Saunders et al., 1997; Sawa et al., 1997; Chen et al., 1999; Cahuana et al., 2004; Hara et al., 2005; Colell et al., 2007; Tarze et al., 2007; Sen et al., 2008; Ou et al., 2010; Thangima Zannat et al., 2011). Furthermore, the involvement of $\alpha / \beta$-tubulin in cell death was also observed in different research models (Ankarcrona et al., 1996; Martin and Baehrecke, 2004; Nolasco et al., 2005; Tracy et al., 2014; Manissorn et al., 2016; Liu et al., 2020). These discoveries bring up concerns about using housekeeping proteins as internal controls in meat quality research because of simultaneous apoptosis in postmortem muscles (Kemp et al., 2006; Kemp et al., 2009; Becila et al., 2010; Cao et al., 2010). Without ruling out the involvement of these housekeeping proteins in postmortem muscle cell death, housekeeping protein normalization could further lead to biased observations of cell death and its related biological processes responsible for meat quality. In actuality, the rapid development and application of mass-spectrometry-based technology in meat quality research has enabled researchers to find the variability of housekeeping proteins in different scenarios. The previous findings of housekeeping proteins as differential proteins and their association with meat quality will be reviewed and discussed in the following sections. The studies are also summarized in Table 1.

\section{Housekeeping Proteins and Proteomics Research in Meat Quality Research}

\section{$\beta$-actin}

Recently, Yu et al. (2018) used label-free mass spectrometry to identify muscle-specific whole proteome variations between 2 muscles with distinct muscle fiber proportion and color stability (beef longissimus lumborum [LL] and psoas major [PM] muscles) at early postmortem periods. The results showed that $\beta$-actin was more abundant in PM than LL throughout early postmortem periods $(1,12$, and $24 \mathrm{~h}$ postmortem), and the fold change ratio (PM vs. LL) varied from 3.83 to 1.69 depending on postmortem time. In a separate study, Gulyas et al. (2018) compared the whole protein fraction 
Table 1. Summary of transcriptomic and proteomic experiments reporting differential housekeeping gene expression or protein expression/modification associated with meat quality

\begin{tabular}{|c|c|c|c|c|c|c|c|c|}
\hline $\begin{array}{l}\text { Housekeeping } \\
\text { gene/protein }\end{array}$ & Species & $\begin{array}{c}\text { Molecular } \\
\text { level }\end{array}$ & Target fraction & Method & $\begin{array}{l}\text { Involved } \\
\text { factor }\end{array}$ & Muscle & $\begin{array}{l}\text { Postmortem } \\
\text { collection } \\
\text { timepoint }\end{array}$ & Reference \\
\hline$\beta$-actin & Pig & mRNA & Total RNA & Real-time qPCR & Breed & LD & $10 \mathrm{~min}$ & $\begin{array}{l}\text { (McBryan } \\
\text { et al., 2010) }\end{array}$ \\
\hline$\beta$-actin & Cattle & Protein & Proteome $^{\mathrm{a}}$ & Label-free MS & $\begin{array}{l}\text { Muscle, } \\
\text { postmortem time }\end{array}$ & LL, PM & 1,12 , and $24 \mathrm{~h}$ & $\begin{array}{l}\text { (Yu et al., } \\
2018 \text { ) }\end{array}$ \\
\hline$\beta$-actin & Lamb & Protein & Proteome & $\begin{array}{l}\text { 2D-PAGE + } \\
\quad \text { MS }\end{array}$ & Breed & LD & $20 \mathrm{~min}$ & $\begin{array}{l}\text { (Gulyas et al., } \\
\text { 2018) }\end{array}$ \\
\hline$\beta$-actin & Lamb & Protein & Proteome & $\begin{array}{l}\text { 2D-PAGE + } \\
\quad \text { MS }\end{array}$ & $\begin{array}{l}\text { Dietary supplement } \\
\text { level }\end{array}$ & SM & $24 \mathrm{~h}$ & $\begin{array}{l}\text { (de Melo } \\
\text { et al., 2020) }\end{array}$ \\
\hline GAPDH & Cattle & Protein & $\begin{array}{l}\text { Soluble/sarcoplasmic } \\
\text { protein fraction }{ }^{\mathrm{b}}\end{array}$ & $\begin{array}{l}\text { 2D-PAGE }+ \\
\text { MS }\end{array}$ & Sex, ultimate $\mathrm{pH}$ & LT & $\begin{array}{l}\text { Between } 24 \\
\text { and } 48 \mathrm{~h}\end{array}$ & $\begin{array}{l}\text { (Mahmood } \\
\text { et al., 2018) }\end{array}$ \\
\hline GAPDH & Cattle & Protein & $\begin{array}{l}\text { Proteome, } \\
\text { phosphoprotein }\end{array}$ & $\begin{array}{l}\text { 2D-PAGE + } \\
\quad \mathrm{MS}\end{array}$ & $\begin{array}{l}\text { Sex, postmortem } \\
\text { time }\end{array}$ & LD & $1,14 \mathrm{~d}$ & $\begin{array}{l}\text { (Silva et al., } \\
\text { 2019) }\end{array}$ \\
\hline GAPDH & Cattle & Protein & $\begin{array}{l}\text { Insoluble/myofibrillar } \\
\text { protein fraction }^{\mathrm{c}}\end{array}$ & $\begin{array}{l}\text { 2D-PAGE }+ \\
\text { MS }\end{array}$ & Postmortem time & LT & $1,48 \mathrm{~h}$ & $\begin{array}{l}\text { (Bjarnadóttir } \\
\text { et al., 2010) }\end{array}$ \\
\hline GAPDH & Cattle & Protein & $\begin{array}{l}\text { Soluble protein } \\
\text { fraction, Insoluble } \\
\text { protein fraction }\end{array}$ & $\begin{array}{l}\text { 2D-PAGE }+ \\
\quad \text { MS }\end{array}$ & $\begin{array}{l}\text { Tenderness, } \\
\text { postmortem time }\end{array}$ & LT & $\begin{array}{l}10 \mathrm{~min}, 5 \mathrm{~d} \text {, } \\
\text { and } 21 \mathrm{~d}\end{array}$ & $\begin{array}{l}\text { (Laville et al., } \\
\text { 2009) }\end{array}$ \\
\hline GAPDH & Cattle & Protein & Proteome & $\begin{array}{l}\text { 2D-PAGE + } \\
\text { MS, 2P- } \\
\text { PAGE + MS }\end{array}$ & Postmortem time & LD & 0,12 , and $26 \mathrm{~d}$ & $\begin{array}{l}\text { (Polati et al., } \\
\text { 2012) }\end{array}$ \\
\hline GAPDH & Cattle & Protein & $\begin{array}{l}\text { Sarcoplasmic/soluble } \\
\text { protein proteins }\end{array}$ & $\begin{array}{c}\text { 1D-PAGE + } \\
\text { MS,2D- } \\
\text { PAGE + MS }\end{array}$ & $\begin{array}{l}\text { Breed, postmortem } \\
\text { time }\end{array}$ & LD & $\begin{array}{c}1,7,14 \text {, and } \\
21 \mathrm{~d}\end{array}$ & $\begin{array}{l}\text { (Marino et al., } \\
\text { 2014) }\end{array}$ \\
\hline GAPDH & Cattle & Protein & Proteome & $\begin{array}{l}\text { 2D-PAGE }+ \\
\quad \mathrm{MS}\end{array}$ & Tenderness & LD & $24 \mathrm{~h}$ & $\begin{array}{l}\text { (D'Alessandro } \\
\text { et al., 2012a) }\end{array}$ \\
\hline GAPDH & Cattle & Protein & Phosphoprotein & $\begin{array}{l}\text { 2D-PAGE }+ \\
\text { MS }\end{array}$ & Tenderness & LD & $24 \mathrm{~h}$ & $\begin{array}{l}\text { (D'Alessandro } \\
\text { et al., 2012b) }\end{array}$ \\
\hline GAPDH & Cattle & Protein & Proteome & $\begin{array}{l}\text { 2D-PAGE }+ \\
\quad \text { MS }\end{array}$ & Drip loss & LD & $45 \mathrm{~min}$ & $\begin{array}{l}\text { (Zuo et al., } \\
2016 \text { ) }\end{array}$ \\
\hline GAPDH & Cattle & Protein & $\begin{array}{l}\text { Sarcoplasmic/soluble } \\
\text { protein fraction }\end{array}$ & $\begin{array}{l}\text { 2D-PAGE }+ \\
\quad \text { MS }\end{array}$ & Color stability & LL & $36 \mathrm{~h}$ & $\begin{array}{l}\text { (Canto et al., } \\
\text { 2015) }\end{array}$ \\
\hline GAPDH & Cattle & Protein & Proteome & $\begin{array}{c}\text { 2D-PAGE }+ \\
\text { MS }\end{array}$ & Dietary supplement & LD & $0 \mathrm{~h}$ & $\begin{array}{l}\text { (Campos } \\
\text { et al., 2020) }\end{array}$ \\
\hline GAPDH & Chicken & Protein & $\begin{array}{l}\text { Sarcoplasmic/soluble } \\
\text { protein fraction }\end{array}$ & Label-free MS & Myopathy level & Pectoralis & $0 \mathrm{~h}$ & $\begin{array}{l}\text { (Kuttappan } \\
\text { et al., 2017) }\end{array}$ \\
\hline GAPDH & Goose & Protein & Proteome & Label-free MS & Drip loss & Pectoralis & $45 \mathrm{~min}$ & $\begin{array}{l}\text { (Zhang et al., } \\
\text { 2019b) }\end{array}$ \\
\hline GAPDH & Pig & RNA & Total RNA & Real-time qPCR & $\begin{array}{l}\text { Intramuscular fat } \\
\text { content }\end{array}$ & LD & $15 \mathrm{~min}$ & $\begin{array}{l}\text { (Hamill et al., } \\
\text { 2012) }\end{array}$ \\
\hline GAPDH & Pig & Protein & Proteome & $\begin{array}{l}\text { 2D-PAGE + } \\
\quad \text { MS }\end{array}$ & Breed & LL & $24 \mathrm{~h}$ & $\begin{array}{l}\text { (D'Alessandro } \\
\text { et al., 2011) }\end{array}$ \\
\hline GAPDH & Pig & Protein & $\begin{array}{l}\text { Sarcoplasmic/soluble } \\
\text { protein fraction }\end{array}$ & $\begin{array}{c}\text { 1D-PAGE }+ \\
\text { MS }\end{array}$ & Genotype & $\mathrm{LT}$ & $20 \mathrm{~min}$ & $\begin{array}{l}\text { (Oliván et al., } \\
\text { 2018) }\end{array}$ \\
\hline GAPDH & Pig & Protein & Proteome & Label-free MS & Muscle portion & LD & $24 \mathrm{~h}$ & $\begin{array}{l}\text { (Kim et al., } \\
\text { 2019) }\end{array}$ \\
\hline GAPDH & Pig & Protein & $\begin{array}{l}\text { Sarcoplasmic/soluble } \\
\text { protein fraction }\end{array}$ & $\begin{array}{l}\text { 1D-PAGE + } \\
\quad \text { WB }\end{array}$ & Health status & LD & $0 \mathrm{~h}$ & $\begin{array}{l}\text { (Patterson } \\
\text { et al., 2021) }\end{array}$ \\
\hline$\alpha / \beta$-tubulin & Cattle & Protein & $\begin{array}{l}\text { Sarcoplasmic/soluble } \\
\text { protein fraction }\end{array}$ & $\begin{array}{c}\text { 2D-PAGE }+ \\
\text { MS }\end{array}$ & Lipid oxidation & LL & $24 \mathrm{~h}$ & $\begin{array}{l}\text { (Sayd et al., } \\
\text { 2012) }\end{array}$ \\
\hline$\alpha$-tubulin & Cattle & Protein & $\begin{array}{l}\text { Sarcoplasmic/soluble } \\
\text { protein fraction }\end{array}$ & 2D-DIGE $+\mathrm{MS}$ & $\begin{array}{l}\text { Muscle, } \\
\text { postmortem time }\end{array}$ & LL, TB & $0,7 \mathrm{~d}$ & $\begin{array}{l}\text { (de Oliveira } \\
\text { et al., 2019) }\end{array}$ \\
\hline $\begin{array}{l}\text { GAPDH, } \\
\alpha / \beta \text {-tubulin }\end{array}$ & Cattle & Protein & $\begin{array}{l}\text { Myofibrillar/insoluble } \\
\text { protein fraction }\end{array}$ & $\begin{array}{l}\text { 1D-PAGE + } \\
\text { MS }\end{array}$ & Tenderness & LD & $36 \mathrm{~h}$ & $\begin{array}{l}\text { (Zapata et al., } \\
\text { 2009) }\end{array}$ \\
\hline
\end{tabular}


Table 1. (Continued)

\begin{tabular}{|c|c|c|c|c|c|c|c|c|}
\hline $\begin{array}{l}\text { Housekeeping } \\
\text { gene/protein }\end{array}$ & Species & $\begin{array}{c}\text { Molecular } \\
\text { level }\end{array}$ & Target fraction & Method & $\begin{array}{l}\text { Involved } \\
\text { factor }\end{array}$ & Muscle & $\begin{array}{l}\text { Postmortem } \\
\text { collection } \\
\text { timepoint }\end{array}$ & Reference \\
\hline $\begin{array}{l}\text { GAPDH, } \\
\alpha / \beta \text {-tubulin }\end{array}$ & Pig & Protein & $\begin{array}{l}\text { Sarcoplasmic/soluble } \\
\text { protein fraction }\end{array}$ & 2D-DIGE + MS & $\begin{array}{l}\text { Heat stress, muscle } \\
\text { portion }\end{array}$ & ST & $0 \mathrm{~h}$ & $\begin{array}{l}\text { (Cruzen et al., } \\
\text { 2015) }\end{array}$ \\
\hline $\begin{array}{l}\text { GAPDH, } \\
\alpha / \beta \text {-tubulin }\end{array}$ & Pig & Protein & $\begin{array}{l}\text { Sarcoplasmic/soluble } \\
\text { protein fraction }\end{array}$ & 2D-DIGE + MS & $\begin{array}{l}\text { Heat stress, stress } \\
\text { duration, muscle } \\
\text { portion }\end{array}$ & ST & $0 \mathrm{~h}$ & $\begin{array}{l}\text { (Cruzen et al. } \\
\text { 2017) }\end{array}$ \\
\hline $\begin{array}{l}\text { GAPDH, } \\
\beta \text {-tubulin }\end{array}$ & Pig & Protein & Proteome & Label-free MS & $\begin{array}{l}\text { Muscle, muscle } \\
\text { portion }\end{array}$ & ST, SM & $24 \mathrm{~h}$ & $\begin{array}{l}\text { (Kim et al., } \\
\text { 2018a) }\end{array}$ \\
\hline $\begin{array}{l}\beta \text {-actin, } \\
\text { GAPDH, } \\
\beta \text {-tubulin }\end{array}$ & Lamb & Protein & Proteome & 2D-DIGE + MS & $\begin{array}{l}\text { Slaughter } \\
\text { method }\end{array}$ & LL & $24 \mathrm{~h}$ & $\begin{array}{l}\text { (Kiran et al., } \\
\text { 2019) }\end{array}$ \\
\hline
\end{tabular}

aProteome: the total amount of proteins expressed at a certain time point in a cell/tissue/animal.

${ }^{b}$ Soluble/sarcoplasmic protein fraction: soluble in water or low ionic strength solution.

'Insoluble/myofibrillar protein fraction: soluble in high ionic strength solution.

1D-PAGE $=$ one-dimensional polyacrylamide gel electrophoresis; 2D-DIGE = two-dimensional differential gel electrophoresis; 2D-PAGE = twodimensional polyacrylamide gel electrophoresis; $2 \mathrm{P}-\mathrm{PAGE}=$ two dimensional polar polyacrylamide gel electrophoresis; LD = longissimus dorsi; $\mathrm{LL}=$ longissimus lumborum; $\mathrm{LT}=$ longissimus thoracis; $\mathrm{mRNA}=$ messenger $\mathrm{RNA} ; \mathrm{MS}=$ mass spectrometry; $\mathrm{PM}=$ psoas major; $\mathrm{qPCR}=$ quantitative $\mathrm{PCR} ; \mathrm{SM}=$ semimembranosus; $\mathrm{ST}=$ semitendinosus; $\mathrm{TB}=$ triceps brachii; $\mathrm{WB}=$ Warner-Bratzler.

of longissimus dorsi (LD) muscle proteome profile between Hungarian Merino and Tsigai sheep at $20 \mathrm{~min}$ postmortem, and their results indicated that Merino sheep had greater (2.6-fold) $\beta$-actin abundance than Tsigai sheep. Kiran et al. (2019) reported that $\beta$-actin quantity was approximately 6.91 times greater in nonstunned lamb LL proteome than stunned lamb. Phenotypically, the nonstunned lamb had a lower ultimate $\mathrm{pH}$, water holding capacity, and Warner-Bratzler shear force than the stunned lamb (Kiran et al., 2019). A more recent study reported that the $\beta$-actin abundance in the proteome of lamb semimembranosus (SM) muscles at $24 \mathrm{~h}$ postmortem could be decreased by $10 \%$ to $15 \%$ with the supplementation of sunflower cake (de Melo et al., 2020), indicating that nutritional intervention could also impact this protein's expression. Overall, the gene expression levels and protein abundance of $\beta$-actin varied between different muscles and within the same muscle from animals with different nutritional interventions, harvest methods, breeds, and postmortem time points. These expression differences resulted from both antemortem and postmortem factors, which potentially makes using $\beta$-actin in western blot normalization an unreliable choice for standardizing postmortem muscle protein quantification.

\section{Glyceraldehyde 3-phosphate dehydrogenase}

GAPDH is a protein that has been reported to have a significant correlation with animal phenotype. For example, in a study that evaluated the proteomics of dark cutting meat, GAPDH appeared to be in greater abundance in the soluble protein fraction of longissimus thoracis (LT) muscle of normal steer carcasses at 24 to $48 \mathrm{~h}$ postmortem as compared to atypical dark cutting steer carcasses $(\mathrm{pH}<5.9)$ and typical dark cutting heifer carcasses ( $\mathrm{pH}>5.9$; Mahmood et al., 2018). GAPDH abundance was also positively correlated with animal age and negatively correlated with dressing percentages and ultimate $\mathrm{pH}$, indicating the association between GAPDH and carcass characteristics (D'Alessandro et al., 2012a). Likewise, D'Alessandro et al. (2011) reported a greater amount of GAPDH in the proteome of pork LL muscle (more than 2-fold) from breeds with slower growth rates and higher fat deposition. At $20 \mathrm{~min}$ postmortem, GAPDH abundance was also shown to be differentially abundant in the soluble protein fraction of pork LT muscle between different RYR1 genotypes (NN/Nn; Oliván et al., 2018). Furthermore, Silva et al. (2019) reported that GAPDH had a greater abundance in the proteome of longissimus muscle from steers than bulls. In a feeding study, vitamin A supplementation elevated GAPDH abundance at $0 \mathrm{~h}$ postmortem in the proteome of bovine longissimus muscle (Campos et al., 2020). These findings suggest that GAPDH expression and abundance could be altered in muscle from animals with differing carcass characteristics, intramuscular fat content, breed, genotypes, sex, and dietary supplement.

It has been demonstrated that animal health status, harvest method, preslaughter stress, and muscle type could affect GAPDH abundance. For instance, a study 
examining different lamb harvest methods indicated that GAPDH had a lower abundance (0.64-fold) in the proteome of nonstunned LL at $24 \mathrm{~h}$ postmortem compared to the LL muscle of stunned lambs (Kiran et al., 2019). In addition, Cruzen et al. (2015) reported that $12 \mathrm{~h}$ heat stress of pigs could increase the abundance of GAPDH in the sarcoplasmic fraction of white semitendinosus (ST) pork muscle at $0 \mathrm{~h}$ postmortem compared to the same muscle from pair-fed thermal neutral pigs; however, no differences in GAPDH abundance due to heat stress were observed in red ST pork muscle. Similar muscle portion-specific differential abundance of GAPDH in the sarcoplasmic protein fraction of ST pork muscle after $2 \mathrm{~h}$ heat stress was reported in another study (Cruzen et al., 2017). Likewise, a greater abundance of GAPDH was observed in the proteome of the light portion of pork ST and SM muscles at $24 \mathrm{~h}$ postmortem than the dark portion (Kim et al., 2018a). In the soluble protein fraction of pork LD muscle, GAPDH had a higher abundance in the medial region at $24 \mathrm{~h}$ postmortem than the anterior regions (Kim et al., 2019). Furthermore, Kuttappan et al. (2017) reported that GAPDH had a lower abundance in the soluble protein fraction of chicken breast with severe myopathic changes at $0 \mathrm{~h}$ postmortem than in the normal breast meat. A recent study also found an increase in oxidized GAPDH in the soluble protein fraction of health-challenged pig LL muscle at $0 \mathrm{~h}$ postmortem by separation on nonreducing gels. Still, no difference was found in reducing gel (Patterson et al., 2021).

Several studies have also reported the dynamic abundance of GAPDH resulting from the aging period. Silva et al. (2019) reported that GAPDH had a greater abundance in the proteome of unaged ( $1 \mathrm{~d}$ postmortem) longissimus muscle compared to aged (14 d postmortem) muscle. Additionally, the intact form of GAPDH decreased in abundance from 1 to $48 \mathrm{~h}$ postmortem in the insoluble protein fraction of bovine LT muscle (Bjarnadóttir et al., 2010). Furthermore, after both 5 and 21 days of the aging period, there was an increase in the fragments of GAPDH, a protein expected to be seen in the soluble fraction, in the insoluble protein fraction of bovine LD muscle (Laville et al., 2009), a trend that was also later observed in the proteome of same muscle during aging (Polati et al., 2012). In agreement with these previous studies, Marino et al. (2014) reported a decreased abundance of GAPDH in the soluble protein fraction of LD muscle during aging (from $1 \mathrm{~d}$ to $21 \mathrm{~d}$ ) within 3 different beef cattle breeds.

Likewise, GAPDH abundance could vary in meat with differing tenderness, water holding capacity, and color stability. Zapata et al. (2009) reported that
GAPDH had greater abundance in the soluble protein fraction of tender beef LD muscle at $36 \mathrm{~h}$ postmortem versus the tough group. Laville et al. (2009) also found that fragments of GAPDH in insoluble protein fractions had a greater abundance in tender LD than tough LD muscle at $5 \mathrm{~d}$ postmortem. In 2 companion studies, the first study demonstrated that GAPDH was in greater abundance (4.5-fold) in the proteome of beef LD muscle perceived as tender at $24 \mathrm{~h}$ postmortem than the beef LD perceived as tough (D'Alessandro et al., 2012a). In contrast, the second study reported that the phosphorylated peptide of GAPDH was found in the proteome of tough but not in the tender group (D'Alessandro et al., 2012b). Another study showed greater GAPDH abundance in the proteome of yak LT muscle with a greater amount of drip loss at 45 min postmortem (Zuo et al., 2016). GAPDH was also more abundant in the soluble protein fraction of color-stable LL steaks at $36 \mathrm{~h}$ postmortem than the color-labile LL steaks (Canto et al., 2015). Furthermore, goose meat with a greater amount of drip loss had a greater GAPDH abundance in the proteome at 45 min postmortem than the low drip group (Zhang et al., 2019b). Certainly, meat color stability and tenderness can be affected by muscle fiber type (Picard and Gagaoua, 2020; Matarneh et al., 2021), and the fiber types are heterogeneous in skeletal muscles. GAPDH is an enzyme associated with glycolysis, and type II muscle fiber is more glycolytic than type I muscle fiber, which could also partially account for the differing GAPDH abundance in each fractions of whole muscle proteome.

To sum up, these observations support the conclusion that GAPDH abundance and modifications can vary in postmortem muscle from the animal with the different genotypes, breed, sex, intramuscular fat content, dietary supplement, slaughter methods, heat stress, and health status. This variation can also be observed in meat with differing ultimate $\mathrm{pH}$, tenderness, color stability, water holding capacity, and aging. GAPDH could undergo different levels of expression, modification, fragmentation, and denaturation by unknown mechanisms resulting from both antemortem and postmortem factors. Due to this variability, GAPDH could be an unstable internal control for western blot normalization in meat science research.

\section{Tubulins}

In meat science research, tubulins have been identified as proteins associated with different quality attributes, such as tenderness and lipid oxidation. 
Zapata et al. (2009) analyzed $36 \mathrm{~h}$ postmortem insoluble protein fractions of beef LD muscle and linearly regressed it against Warner-Bratzler (WB) shear force (toughness) values. They observed that WB shear force was associated with the abundance of tubulins $(\beta-2 \mathrm{C}$ chain, $\beta-3$ chain, $\alpha-3$ chain, and $\alpha-4 \mathrm{~A}$ chain) and their fragments. Another study reported that the abundance of a tubulin dimer $(\alpha-\beta)$ fragment in the soluble protein fraction of beef LL muscle at 30 min postmortem was positively associated with lipid oxidation at $24 \mathrm{~h}$ postmortem (Sayd et al., 2012).

Likewise, harvest method, heat stress, muscle type/ portion, and aging period could also alter tubulin expression. In the proteome of lamb LL muscle, tubulin $\beta-4 \mathrm{~B}$ chains were 2.94 times more abundant in nonstunned lamb at $24 \mathrm{~h}$ postmortem than stunned lamb (Kiran et al., 2019). Research on pork reported that $12 \mathrm{~h}$ heat stress of the animal decreased the abundance of tubulins ( $\alpha$ and $\beta$ ) in the soluble protein fraction of white ST muscle at $0 \mathrm{~h}$ postmortem compared to the thermal neutral group (Cruzen et al., 2015). However, this difference was not observed in the red ST muscle (Cruzen et al., 2015). Further studies reported that $\alpha$ and $\beta$ tubulin abundances in the soluble protein fraction of red and white ST decreased by $2 \mathrm{~h}$ heat stress of the animal. Still, this difference was only observed in red ST when the heat stress was extended to 4 and $6 \mathrm{~h}$ (Cruzen et al., 2017). In addition, $\beta$-tubulin had differential abundance in the proteome between the light and dark portions in pork ST muscle (Kim et al., 2018a). Nevertheless, this difference did not exist in the SM muscle (Kim et al., 2018a). In the soluble protein fraction of both bovine LL and triceps brachii muscles, tubulin $\alpha-4 \mathrm{~A}$ chains were less abundant at $7 \mathrm{~d}$ than 0 d postmortem (de Oliveira et al., 2019). In summary, as with $\beta$-actin and GAPDH, the tubulins were also differentially abundant in the postmortem muscle depending on antemortem stress and slaughter methods and in meat with differing lipid oxidation status, aging periods, muscle portion, muscle type, and tenderness. These antemortem and postmortem factors could change the fragmentation or denaturation of tubulins. Such reports of variation in abundance of housekeeping proteins are of concern and could change the context of results.

Variation in housekeeping gene expression was also reported by transcriptomic studies focusing on meat quality. A real-time quantitative PCR study (McBryan et al., 2010) tested a set of stably expressed endogenous control genes (including gene $A C T B$ coding for $\beta$-actin) for messenger RNA (mRNA) expression in the porcine LD muscle from 3 pig breeds to identify potential candidate genes associated with drip loss. The results indicated that ACTB was one of the least stably expressed genes among the genes examined (McBryan et al., 2010). In addition, the transcriptomic analysis revealed that the gene coding for GAPDH was downregulated in pork LD with higher intramuscular fat content (Hamill et al., 2012).

Overall, several studies have indicated variation in abundance of housekeeping proteins, which could be a concern because it could change the interpretation and conclusion drawn from the results. Using popular housekeeping proteins like $\beta$-actin, GAPDH, and tubulins $(\alpha$ and $\beta)$ as internal controls in meat quality research could result in poor data normalization and a confounded experimental design unable to address the researcher's questions. Researchers from different scientific fields have developed and verified alternative methods instead of using housekeeping proteins as loading controls. The following section will briefly introduce some of these available methods and their properties on polyvinylidene fluoride (PVDF) membrane.

\section{Alternative to High-Abundance Single-Protein Controls}

The purpose of any loading control is to estimate the total protein amount transferred to the blotting membrane in each lane. From this perspective, it is logical to stain the total protein on the blot to understand the total protein amount. Total protein staining represents the true loading amount more accurately than housekeeping proteins and can help account for minor technical and biological variations (Ruan and Lai, 2007; Li and Shen, 2013; Moritz, 2017). The broader dynamic range of total protein stain solves the issue of housekeeping proteins that commonly fail to show loading differences above small loading amounts $(10 \mu \mathrm{g})$ (Moritz, 2017). Total protein staining assays based on stains like Coomassie R-350/G-250, Amido Black, Ponceau S, and Sypro Ruby or even stain-free techniques can be used as an alternative option for loading controls. In the following subsections, the properties of some of these total protein staining approaches are briefly summarized. The protocols for these not included in this section but are described in detail by Goldman et al. (2016).

\section{Coomassie blue}

Coomassie blue forms strong but noncovalent bonds by electrostatic interactions with proteins 
containing the basic amino acids, arginine, and lysine (Congdon et al., 1993). This results in visible staining of protein on the membrane. Additionally, Coomassie blue does not need a fluorescence detection system to visualize the staining; its dynamic range of protein loading amount is linear and could extend from 1 to $30 \mu \mathrm{g} /$ lane (R-350) or 5 to $50 \mu \mathrm{g} / \mathrm{lane}$ (G-250) (Welinder and Ekblad, 2011; Thacker et al., 2016; Moritz, 2017). The staining process is relatively quick ( $5 \mathrm{~min}$ ) and does not interfere with subsequent mass spectrometry analysis (Goldman et al., 2016). However, the disadvantage of the method is its affinity with different proteins: the absorbance change per unit mass of proteins varies with the type of the protein (Congdon et al., 1993), primarily due to the differences in numbers of arginine and lysine residues among different proteins.

\section{Ponceau $S$}

Ponceau $\mathrm{S}$ is a negatively charged sodium salt of a diazo dye that reversibly binds to positively charged amino acids and nonpolar regions of proteins. Similar to Coomassie blue, fluorescence detection systems are not needed for stain visualization. Ponceau $\mathrm{S}$ has an almost linear dynamic range of protein loading amount, conservatively, from 5 to $50 \mu \mathrm{g} /$ lane on PVDF membrane (Thacker et al., 2016; Moritz, 2017). Its performance is superior compared to the loading controls based on $\beta$-actin, GAPDH, $\alpha$-tubulin, or total protein staining with Coomassie due to less variation across tissues and a relatively larger linear dynamic range (Romero-Calvo et al., 2010; Lanoix et al., 2012; Gilda and Gomes, 2013; Fortes et al., 2016; Thacker et al., 2016). Nevertheless, this staining method might be less sensitive to small loading differences that commonly occur in western blots because of its less steep calibration curve (Gilda and Gomes, 2013). Ponceau S staining on blotting membranes is rapid (30 s to $1 \mathrm{~min}$; Goldman et al., 2016) and does not affect subsequent analytical techniques.

\section{Amido Black}

Amido Black noncovalently binds to arginine, histidine, and lysine and the terminal amino group by electrostatic interaction (Racusen, 1973). No special devices are needed for stain visualization. Amido Black has a linear dynamic range for protein loading amount from 22 to $41 \mu \mathrm{g} /$ lane on PVDF membrane (Aldridge et al., 2008; Moritz, 2017). It was shown to be more accurate in reflecting differences in protein concentration when compared to the immunosignals of $\beta$-actin, GAPDH, and $\alpha$-tubulin due to its more extensive linear dynamic range and less variability across tissues (Aldridge et al., 2008; Lanoix et al., 2012). Amido Black staining is a permanent (because of irreversible staining of proteins on membranes) and quick (1 min) stain that can be used to normalize total protein after immunodetection. Amido Black has similar sensitivity (50 ng) with Coomassie blue but higher than Ponceau S (200 ng) (Goldman et al., 2016) and does not affect subsequent protein sequencing.

\section{Sypro Ruby}

Sypro Ruby is a fluorescent stain based on an organic compound containing ruthenium that interacts noncovalently with proteins (Berggren et al., 1999). The dynamic range of protein loading amount of this total protein stain could run conservatively from 10 to $40 \mu \mathrm{g} / \mathrm{lane}$ on the PVDF membrane (Colella et al., 2012; Moritz, 2017). Due to the inconsistent results in its staining behavior (linear or logarithmic) from previous studies (Colella et al., 2012; Moritz et al., 2014), it is recommended to test its staining behavior with the interested dilution series and detection instrument before formal analysis (Moritz, 2017). Sypro Ruby was shown to be more accurate and stable in reflecting the differences in protein loading amount than using GAPDH and $\beta$-actin and was therefore suggested as a superior loading control compared to these housekeeping proteins (Aldridge et al., 2008; Hu et al., 2016). Unlike the protein staining methods mentioned earlier, a fluorescence imager is necessary to visualize the fluorescence emitted by Sypro Ruby staining but is relatively fast (15 min; Goldman et al., 2016). However, for unknown reasons, Sypro Ruby can inhibit the identification of cysteine and tryptophancontaining peptides for peptide mass fingerprinting using MALDI-MS, which lowers its compatibility with subsequent mass spectrometry analysis (Ball and Karuso, 2007).

\section{Stain-free technique}

The stain-free technique is based on trihalo compounds, such as trichloroethanol, incorporated into polyacrylamide gels. The staining compound can form covalent bonds with tryptophan residues of proteins under ultraviolet exposure (Ladner et al., 2004). These covalent bonds are detectable on gels and protein-transferred membranes (Colella et al., 2012; Gilda and Gomes, 2013; Gürtler et al., 2013). Conservatively, its linear dynamic range of protein loading amount comprises loading amounts between 10 and $40 \mu \mathrm{g} /$ lane on PVDF membrane (Moritz, 2017), and many studies 
have confirmed its superiority to the use of GAPDH and $\beta$-actin (Colella et al., 2012; Gilda and Gomes, 2013; Gürtler et al., 2013; Rivero-Gutiérrez et al., 2014). A fluorescent imager is needed for the detection of fluorescent emissions on the membrane. However, it has been reported that the stain-free method may not work when less than 3 to $5 \mu \mathrm{g}$ of total protein is loaded per lane (Taylor et al., 2013). Another disadvantage could result from its staining mechanism of action. The proteins lacking tryptophan could be invisible and may lead to a bias due to its specific binding with tryptophan residues (Moritz, 2017).

\section{Other techniques}

Previous literature has also proposed other reversible total staining methods used as the internal control in western blot. Fluorescent staining methods, like epicocconone (Moritz et al., 2014), and nonfluorescent staining methods, like MemCode (Antharavally et al., 2004), have been documented. Epicocconone noncovalently interacts with sodium dodecyl sulfate (SDS) and proteins (Bell and Karuso, 2003; Mackintosh et al., 2003) with a logarithmic dynamic range of protein loading from 0.1 to $30 \mu \mathrm{g}$ per lane on the PVDF membrane (Moritz et al., 2014). MemCode can also noncovalently react with protein, but its dynamic range and regression model of staining behavior has not been tested (Antharavally et al., 2004).

Overall, the total protein staining method should be selected depending on the researcher's question and experimental design. Researchers should avoid using staining dye with a binding mechanism that could lead to staining bias. Postmortem muscle is proteolytic, and the extent of proteolysis can be affected by multiple factors such as muscle type and aging period. Due to protein degradation during aging, there is a potential for the protein profile to shift from a higher molecular weight range to lower region. This could in turn affect the total protein signal within a region. Therefore, depending on the extraction method, researchers should account for the dynamic shift of protein profile and choose a stable range of molecular weight of total protein for signal normalization. Furthermore, it is important for researchers to be conscious of the dayto-day bias of these total staining methods. For example, it is common for a total protein staining method that the staining background has variations between different blots. This background variation could generate technical errors and further affect normalization accuracy. Nevertheless, this problem could be minimized by the incorporation of an internal reference sample onto every blot. After normalization of the interested protein to total protein staining, the obtained band intensity can be compared to this reference sample.

\section{Conclusions}

Multiple research studies have reported concerns regarding the use of housekeeping proteins such $\beta$ actin, GAPDH, and tubulins as internal control for western blots. Direct measurement of the actual amount of protein loaded by total protein staining methods can reduce technical errors and commonly used housekeeping proteins' biological variation. The broad dynamic range of total protein staining methods can also solve the limitations with a small loading amount resulting from housekeeping protein saturation. Therefore, using total protein staining in meat science western blot experiments could avoid biased results due to housekeeping protein differential abundances caused by the antemortem and postmortem factors and, therefore, can help explore the molecular mechanism behind meat quality variation.

\section{Acknowledgements}

The authors declare no competing financial interest. This manuscript was partially supported by USDA multistate grant W4177.

\section{Literature Cited}

Aldridge, G. M., D. M. Podrebarac, W. T. Greenough, and I. J. Weiler. 2008. The use of total protein stains as loading controls: An alternative to high-abundance single-protein controls in semi-quantitative immunoblotting. J. Neurosci. Meth. 172:250-254. https://doi.org/10.1016/j.jneumeth.2008.05. 003.

Alwine, J. C., D. J. Kemp, and G. R. Stark. 1977. Method for detection of specific RNAs in agarose gels by transfer to diazobenzyloxymethyl-paper and hybridization with DNA probes. P. Natl. Acad. Sci. USA. 74:5350-5354. https://doi.org/10. 1073/pnas.74.12.5350.

Ankarcrona, M., B. Zhivotovsky, T. Holmström, A. Diana, J. E. Eriksson, S. Orrenius, and P. Nicotera. 1996. Lamin and $\beta$ tubulin fragmentation precede chromatin degradation in glutamate-induced neuronal apoptosis. NeuroReport. 7:26592664. https://doi.org/10.1097/00001756-199611040-00050.

Antharavally, B. S., B. Carter, P. A. Bell, and A. Krishna Mallia. 2004. A high-affinity reversible protein stain for western blots. Anal. Biochem. 329:276-280. https://doi.org/10. 1016/j.ab.2004.02.049

Arruda, D. C., L. C. P. Santos, F. M. Melo, F. V. Pereira, C. R. Figueiredo, A. L. Matsuo, R. A. Mortara, M. A. Juliano, 
E. G. Rodrigues, A. S. Dobroff, L. Polonelli, and L. R. Travassos. 2012. $\beta$-actin-binding complementarity-determining region 2 of variable heavy chain from monoclonal antibody C7 induces apoptosis in several human tumor cells and is protective against metastatic melanoma. J. Biol. Chem. 287: 14912-14922. https://doi.org/10.1074/jbc.M111.322362.

Ball, M. S., and P. Karuso. 2007. Mass spectral compatibility of four proteomics stains. J. Proteome Res. 6:4313-4320. https://doi.org/10.1021/pr070398z.

Becila, S., C. H. Herrera-Mendez, G. Coulis, R. Labas, T. Astruc, B. Picard, A. Boudjellal, P. Pelissier, L. Bremaud, and A. Ouali. 2010. Postmortem muscle cells die through apoptosis. Eur. Food Res. Technol. 231:485-493. https://doi.org/10.1007/ s00217-010-1296-5.

Bekhit, A. E.-D. A., D. L. Hopkins, F. T. Fahri, and E. N. Ponnampalam. 2013. Oxidative processes in muscle systems and fresh meat: sources, markers, and remedies. Compr. Rev. Food Sci. F. 12:565-597. https://doi.org/10.1111/1541-4337. 12027.

Bell, P. J. L., and P. Karuso. 2003. Epicocconone, a novel fluorescent compound from the fungus Epicoccum nigrum. J. Am. Chem. Soc. 125:9304-9305. https://doi.org/10.1021/ ja035496+.

Berggren, K., T. H. Steinberg, W. M. Lauber, J. A. Carroll, M. F. Lopez, E. Chernokalskaya, L. Zieske, Z. Diwu, R. P. Haugland, and W. F. Patton. 1999. A luminescent ruthenium complex for ultrasensitive detection of proteins immobilized on membrane supports. Anal. Biochem. 276:129-143. https:// doi.org/10.1006/abio.1999.4364.

Berry, D. P., S. Conroy, T. Pabiou, and A. R. Cromie. 2017. Animal breeding strategies can improve meat quality attributes within entire populations. Meat Sci. 132:6-18. https://doi.org/10. 1016/j.meatsci.2017.04.019.

Bettencourt, J. W., A. R. McLaury, A. K. Limberg, J. S. VargasHernandez, B. Bayram, A. R. Owen, D. J. Berry, J. Sanchez-Sotelo, M. E. Morrey, A. J. van Wijnen, and M. P. Abdel. 2020. Total protein staining is superior to classical or tissue-specific protein staining for standardization of protein biomarkers in heterogeneous tissue samples. Gene Reports. 19:100641. https://doi.org/10.1016/j.genrep.2020.100641.

Bjarnadóttir, S. G., K. Hollung, E. M. Færgestad, and E. VeisethKent. 2010. Proteome changes in bovine Longissimus thoracis muscle during the first $48 \mathrm{~h}$ postmortem: Shifts in energy status and myofibrillar stability. J. Agr. Food Chem. 58:74087414. https://doi.org/10.1021/jf100697h.

Burnette, W. N. 1981. "Western blotting”: electrophoretic transfer of proteins from sodium dodecyl sulfate-polyacrylamide gels to unmodified nitrocellulose and radiographic detection with antibody and radioiodinated protein A. Anal. Biochem. 112:195203. https://doi.org/10.1016/0003-2697(81)90281-5.

Cahuana, G. M., J. R. Tejedo, J. Jiménez, R. Ramírez, F. Sobrino, and F. J. Bedoya. 2004. Nitric oxide-induced carbonylation of Bcl-2, GAPDH and ANT precedes apoptotic events in insulinsecreting RINm5F cells. Exp. Cell Res. 293:22-30. https:// doi.org/10.1016/j.yexcr.2003.10.004.

Campos, C. F., T. C. Costa, R. T. S. Rodrigues, S. E. F. Guimarães, F. H. Moura, W. Silva, M. L. Chizzotti, P. V. R. Paulino, P. D. B. Benedeti, F. F. Silva, and M. S. Duarte. 2020. Proteomic analysis reveals changes in energy metabolism of skeletal muscle in beef cattle supplemented with vitamin A. J. Sci. Food Agr. 100:3536-3543. https://doi.org/10.1002/jsfa. 10401.

Canto, A. C. V. C. S., S. P. Suman, M. N. Nair, S. Li, G. Rentfrow, C. M. Beach, T. J. P. Silva, T. L. Wheeler, S. D. Shackelford, A. Grayson, R. O. McKeith, and D. A. King. 2015. Differential abundance of sarcoplasmic proteome explains animal effect on beef Longissimus lumborum color stability. Meat Sci. 102:90-98. https://doi.org/10.1016/j.meatsci. 2014.11.011.

Cao, J., W. Sun, G. Zhou, X. Xu, Z. Peng, and Z. Hu. 2010. Morphological and biochemical assessment of apoptosis in different skeletal muscles of bulls during conditioning. J. Anim. Sci. 88:3439-3444. https://doi.org/10.2527/jas.2009-2412.

Chen, R.-W., P. A. Saunders, H. Wei, Z. Li, P. Seth, and D.-M. Chuang. 1999. Involvement of glyceraldehyde-3-phosphate dehydrogenase (GAPDH) and p53 in neuronal apoptosis: Evidence that GAPDH is upregulated by p53. J. Neurosci. 19:9654-9662. https://doi.org/10.1523/JNEUROSCI. 19-21-09654.1999.

Chen, X., L. Zhang, J. Li, F. Gao, and G. Zhou. 2017. Hydrogen peroxide-induced change in meat quality of the breast muscle of broilers is mediated by ROS generation, apoptosis, and autophagy in the NF- $\mathrm{KB}$ signal pathway. J. Agr. Food Chem. 65:3986-3994. https://doi.org/10.1021/acs.jafc. $7 \mathrm{~b} 01267$.

Chuang, D.-M., and R. Ishitani. 1996. A role for GAPDH in apoptosis and neurodegeneration. Nat. Med. 2:609-610. https:// doi.org/10.1038/nm0696-609.

Colell, A., J.-E. Ricci, S. Tait, S. Milasta, U. Maurer, L. BouchierHayes, P. Fitzgerald, A. Guio-Carrion, N. J. Waterhouse, C. W. Li, B. Mari, P. Barbry, D. D. Newmeyer, H. M. Beere, and D. R. Green. 2007. GAPDH and autophagy preserve survival after apoptotic cytochrome $c$ release in the absence of caspase activation. Cell. 129:983-997. https://doi.org/10. 1016/j.cell.2007.03.045.

Colella, A. D., N. Chegenii, M. N. Tea, I. L. Gibbins, K. A. Williams, and T. K. Chataway. 2012. Comparison of StainFree gels with traditional immunoblot loading control methodology. Anal. Biochem. 430:108-110. https://doi.org/10. 1016/j.ab.2012.08.015.

Congdon, R. W., G. W. Muth, and A. G. Splittgerber. 1993. The binding interaction of Coomassie blue with proteins. Anal. Biochem. 213:407-413. https://doi.org/10.1006/abio.1993. 1439.

Cramer, T., M. L. Penick, J. N. Waddell, C. A. Bidwell, and Y. H. B. Kim. 2018. A new insight into meat toughness of callipyge lamb loins - The relevance of anti-apoptotic systems to decreased proteolysis. Meat Sci. 140:66-71. https://doi.org/ 10.1016/j.meatsci.2018.03.002.

Cruzen, S. M., L. H. Baumgard, N. K. Gabler, S. C. Pearce, and S. M. Lonergan. 2017. Temporal proteomic response to acute heat stress in the porcine muscle sarcoplasm. J. Anim. Sci. 95:3961-3971. https://doi.org/10.2527/jas.2017.1375.

Cruzen, S. M., S. C. Pearce, L. H. Baumgard, N. K. Gabler, E. HuffLonergan, and S. M. Lonergan. 2015. Proteomic changes to the sarcoplasmic fraction of predominantly red or white muscle following acute heat stress. J. Proteomics. 128:141153. https://doi.org/10.1016/j.jprot.2015.07.032. 
D'Alessandro, A., C. Marrocco, V. Zolla, M. D'Andrea, and L. Zolla. 2011. Meat quality of the longissimus lumborum muscle of Casertana and Large White pigs: Metabolomics and proteomics intertwined. J. Proteomics. 75:610-627. https://doi.org/10.1016/j.jprot.2011.08.024.

D’Alessandro, A., C. Marrocco, S. Rinalducci, C. Mirasole, S. Failla, and L. Zolla. 2012a. Chianina beef tenderness investigated through integrated Omics. J. Proteomics. 75:43814398. https://doi.org/10.1016/j.jprot.2012.03.052.

D’Alessandro, A., S. Rinalducci, C. Marrocco, V. Zolla, F. Napolitano, and L. Zolla. 2012b. Love me tender: An Omics window on the bovine meat tenderness network. J. Proteomics. 75:4360-4380. https://doi.org/10.1016/j.jprot. 2012.02.013.

de Melo, A. M. P., M. López-Pedrouso, R. G. Costa, D. Franco, A. de Alencar Araripe Noronha Moura, T. A. da Silva, F. B. M. B. Moreno, V. de Lima Júnior, A. C. de Oliveira MonteiroMoreira, A. N. de Medeiros, R. de Azevedo Moreira, and J. M. Lorenzo. 2020. Proteome changes in lamb semimembranosus muscles associated with the inclusion of sunflower cake in their diet. Int. J. Food Sci. Tech. 55:995-1001. https://doi. org/10.1111/ijfs.14328.

de Oliveira, L. G., E. F. Delgado, E. M. Steadham, E. HuffLonergan, and S. M. Lonergan. 2019. Association of calpain and calpastatin activity to postmortem myofibrillar protein degradation and sarcoplasmic proteome changes in bovine Longissiumus lumborum and Triceps brachii. Meat Sci. 155:50-60. https://doi.org/10.1016/j.meatsci.2019.04.015.

Dittmer, A., and J. Dittmer. 2006. $\beta$-Actin is not a reliable loading control in western blot analysis. ELECTROPHORESIS. 27:2844-2845. https://doi.org/10.1002/elps.200500785.

Eaton, S. L., S. L. Roche, M. Llavero Hurtado, K. J. Oldknow, C. Farquharson, T. H. Gillingwater, and T. M. Wishart. 2013. Total protein analysis as a reliable loading control for quantitative fluorescent western blotting. PLOS ONE. 8:e72457. https://doi.org/10.1371/journal.pone.0072457.

Ferguson, R. E., H. P. Carroll, A. Harris, E. R. Maher, P. J. Selby, and R. E. Banks. 2005. Housekeeping proteins: A preliminary study illustrating some limitations as useful references in protein expression studies. PROTEOMICS. 5:566-571. https:// doi.org/10.1002/pmic.200400941.

Fortes, M. A. S., G. N. Marzuca-Nassr, K. F. Vitzel, C. H. da Justa Pinheiro, P. Newsholme, and R. Curi. 2016. Housekeeping proteins: How useful are they in skeletal muscle diabetes studies and muscle hypertrophy models? Anal. Biochem. 504:3840. https://doi.org/10.1016/j.ab.2016.03.023.

Gilda, J. E., and A. V. Gomes. 2013. Stain-Free total protein staining is a superior loading control to $\beta$-actin for western blots. Anal. Biochem. 440:186-188. https://doi.org/10.1016/j.ab. 2013.05.027.

Goldman, A., S. Harper, and D. W. Speicher. 2016. Detection of proteins on blot membranes. Current Protocols in Protein Science. 86:10.8.1-10.8.11. https://doi.org/10.1002/cpps.15.

Gonzalez-Rivas, P. A., S. S. Chauhan, M. Ha, N. Fegan, F. R. Dunshea, and R. D. Warner. 2020. Effects of heat stress on animal physiology, metabolism, and meat quality: A review. Meat Sci. 162:108025. https://doi.org/10.1016/j.meatsci. 2019.108025 .
Guénal, I., Y. Risler, and B. Mignotte. 1997. Down-regulation of actin genes precedes microfilament network disruption and actin cleavage during p53-mediated apoptosis. J. Cell Sci. 110:489-495.

Gulyas, G., K. Pohoczky, E. Csosz, A. Simon, A. Javor, and L. Czegledi. 2018. Comparative proteome analysis of skeletal muscle between Merino and Tsigai lambs. Small Ruminant Res. 158:35-41. https://doi.org/10.1016/j.smallrumres.2017. 12.003

Gürtler, A., N. Kunz, M. Gomolka, S. Hornhardt, A. A. Friedl, K. McDonald, J. E. Kohn, and A. Posch. 2013. Stain-Free technology as a normalization tool in western blot analysis. Anal. Biochem. 433:105-111. https://doi.org/10.1016/j.ab.2012. 10.010

Hamill, R. M., J. McBryan, C. McGee, A. M. Mullen, T. Sweeney, A. Talbot, M. T. Cairns, and G. C. Davey. 2012. Functional analysis of muscle gene expression profiles associated with tenderness and intramuscular fat content in pork. Meat Sci. 92:440-450. https://doi.org/10.1016/j.meatsci.2012.05.007.

Hara, M. R., N. Agrawal, S. F. Kim, M. B. Cascio, M. Fujimuro, Y. Ozeki, M. Takahashi, J. H. Cheah, S. K. Tankou, L. D. Hester, C. D. Ferris, S. D. Hayward, S. H. Snyder, and A. Sawa. 2005. $S$-nitrosylated GAPDH initiates apoptotic cell death by nuclear translocation following Siah1 binding. Nat. Cell Biol. 7:665-674. https://doi.org/10.1038/ncb1268.

Higdon, R., and E. Kolker. 2015. Can "normal” protein expression ranges be estimated with high-throughput proteomics? J. Proteome Res. 14:2398-2407. https://doi.org/10.1021/acs. jproteome.5b00176.

Hu, X., S. Du, J. Yu, X. Yang, C. Yang, D. Zhou, Q. Wang, S. Qin, X. Yan, L. He, D. Han, and C. Wan. 2016. Common housekeeping proteins are upregulated in colorectal adenocarcinoma and hepatocellular carcinoma, making the total protein a better "housekeeper." Oncotarget. 7:66679-66688. https://doi.org/10.18632/oncotarget.11439.

Ishitani, R., and D. M. Chuang. 1996. Glyceraldehyde-3-phosphate dehydrogenase antisense oligodeoxynucleotides protect against cytosine arabinonucleoside-induced apoptosis in cultured cerebellar neurons. P. Natl. Acad. Sci. USA. 93:99379941. https://doi.org/10.1073/pnas.93.18.9937.

Ishitani, R., M. Kimura, K. Sunaga, N. Katsube, M. Tanaka, and D. M. Chuang. 1996. An antisense oligodeoxynucleotide to glyceraldehyde-3-phosphate dehydrogenase blocks age-induced apoptosis of mature cerebrocortical neurons in culture. J. Pharmacol. Exp. Ther. 278:447-454.

Jiang, J., and Y. L. Xiong. 2016. Natural antioxidants as food and feed additives to promote health benefits and quality of meat products: A review. Meat Sci. 120:107-117. https://doi.org/ 10.1016/j.meatsci.2016.04.005.

Kemp, C. M., R. G. Bardsley, and T. Parr. 2006. Changes in caspase activity during the postmortem conditioning period and its relationship to shear force in porcine longissimus muscle1. J. Anim. Sci. 84:2841-2846. https://doi.org/10.2527/jas. 2006-163.

Kemp, C. M., D. A. King, S. D. Shackelford, T. L. Wheeler, and M. Koohmaraie. 2009. The caspase proteolytic system in callipyge and normal lambs in longissimus, semimembranosus, and infraspinatus muscles during postmortem storage. J. 
Anim. Sci. 87:2943-2951. https://doi.org/10.2527/jas. 2009-1790.

Kim, G.-D., J.-Y. Jeong, H.-S. Yang, and S. J. Hur. 2019. Differential abundance of proteome associated with intramuscular variation of meat quality in porcine longissimus thoracis et lumborum muscle. Meat Sci. 149:85-95. https://doi.org/10. 1016/j.meatsci.2018.11.012.

Kim, G.-D., H.-S. Yang, and J.-Y. Jeong. 2018a. Intramuscular variations of proteome and muscle fiber type distribution in semimembranosus and semitendinosus muscles associated with pork quality. Food Chem. 244:143-152. https://doi.org/10. 1016/j.foodchem.2017.10.046.

Kim, Y. H. B., D. Ma, D. Setyabrata, M. M. Farouk, S. M. Lonergan, E. Huff-Lonergan, and M. C. Hunt. 2018b. Understanding postmortem biochemical processes and postharvest aging factors to develop novel smart-aging strategies. Meat Sci. 144:74-90. https://doi.org/10.1016/j.meatsci.2018. 04.031.

Kiran, M., B. M. Naveena, M. Smrutirekha, P. Baswa Reddy, B. Rituparna, Y. Praveen Kumar, Ch. Venkatesh, and S. Rapole. 2019. Traditional halal slaughter without stunning versus slaughter with electrical stunning of sheep (Ovis aries). Meat Sci. 148:127-136. https://doi.org/10.1016/j.meatsci. 2018.10.011.

Kuttappan, V. A., W. Bottje, R. Ramanathan, S. D. Hartson, C. N. Coon, B.-W. Kong, C. M. Owens, M. Vazquez-Añon, and B. M. Hargis. 2017. Proteomic analysis reveals changes in carbohydrate and protein metabolism associated with broiler breast myopathy. Poult. Sci. 96:2992-2999. https://doi.org/10.3382/ ps/pex069.

Ladner, C. L., J. Yang, R. J. Turner, and R. A. Edwards. 2004. Visible fluorescent detection of proteins in polyacrylamide gels without staining. Anal. Biochem. 326:13-20. https:// doi.org/10.1016/j.ab.2003.10.047.

Lanoix, D., J. St-Pierre, A.-A. Lacasse, M. Viau, J. Lafond, and C. Vaillancourt. 2012. Stability of reference proteins in human placenta: General protein stains are the benchmark. Placenta. 33:151-156. https://doi.org/10.1016/j.placenta. 2011.12.008.

Laville, E., T. Sayd, M. Morzel, S. Blinet, C. Chambon, J. Lepetit, G. Renand, and J. F. Hocquette. 2009. Proteome changes during meat aging in tough and tender beef suggest the importance of apoptosis and protein solubility for beef aging and tenderization. J. Agr. Food Chem. 57:10755-10764. https:// doi.org/10.1021/jf901949r.

Li, J., Q. Li, C. Xie, H. Zhou, Y. Wang, N. Zhang, H. Shao, S. C. Chan, X. Peng, S.-C. Lin, and J. Han. 2004. $\beta$-actin is required for mitochondria clustering and ROS generation in TNFinduced, caspase-independent cell death. J. Cell Sci. 117:4673-4680. https://doi.org/10.1242/jcs.01339.

Li, R., and Y. Shen. 2013. An old method facing a new challenge: Re-visiting housekeeping proteins as internal reference control for neuroscience research. Life Sci. 92:747-751. https:// doi.org/10.1016/j.lfs.2013.02.014.

Li, Z., M. Li, X. Li, J. Xin, Y. Wang, Q. W. Shen, and D. Zhang. 2018. Quantitative phosphoproteomic analysis among muscles of different color stability using tandem mass tag labeling. Food Chem. 249:8-15. https://doi.org/10.1016/j. foodchem.2017.12.047.
Li, Z., X. Li, Z. Wang, Q. W. Shen, and D. Zhang. 2016. Antemortem stress regulates protein acetylation and glycolysis in postmortem muscle. Food Chem. 202:94-98. https://doi. org/10.1016/j.foodchem.2016.01.085.

Liu, R., S. Lonergan, E. Steadham, G. Zhou, W. Zhang, and E. Huff-Lonergan. 2019. Effect of nitric oxide and calpastatin on the inhibition of $\mu$-calpain activity, autolysis and proteolysis of myofibrillar proteins. Food Chem. 275:77-84. https:// doi.org/10.1016/j.foodchem.2018.09.104.

Liu, Y.-J., Y.-J. Chang, Y.-T. Kuo, and P.-H. Liang. 2020. Targeting $\beta$-tubulin/CCT- $\beta$ complex induces apoptosis and suppresses migration and invasion of highly metastatic lung adenocarcinoma. Carcinogenesis. 41:699-710. https://doi. org/10.1093/carcin/bgz137.

Longo, V., A. Lana, M. T. Bottero, and L. Zolla. 2015. Apoptosis in muscle-to-meat aging process: The omic witness. J. Proteomics. 125:29-40. https://doi.org/10.1016/j.jprot.2015. 04.023

Ma, D., and Y. H. B. Kim. 2020. Proteolytic changes of myofibrillar and small heat shock proteins in different bovine muscles during aging: Their relevance to tenderness and water-holding capacity. Meat Sci. 163:108090. https://doi.org/10.1016/j. meatsci.2020.108090.

Ma, D., Q. Yu, V. E. Hedrick, B. R. Cooper, T. J. Paschoal Sobreira, J.-H. Oh, H. Chun, and Y. H. B. Kim. 2020. Proteomic and metabolomic profiling reveals the involvement of apoptosis in meat quality characteristics of ovine $M$. longissimus from different callipyge genotypes. Meat Sci. 166:108140. https://doi.org/10.1016/j.meatsci.2020.108140.

Mackintosh, J. A., H.-Y. Choi, S.-H. Bae, D. A. Veal, P. J. Bell, B. C. Ferrari, D. D. Van Dyk, N. M. Verrills, Y.-K. Paik, and P. Karuso. 2003. A fluorescent natural product for ultra sensitive detection of proteins in one-dimensional and two-dimensional gel electrophoresis. PROTEOMICS. 3:2273-2288. https:// doi.org/10.1002/pmic.200300578.

Mahmood, S., N. Turchinsky, F. Paradis, W. T. Dixon, and H. L. Bruce. 2018. Proteomics of dark cutting longissimus thoracis muscle from heifer and steer carcasses. Meat Sci. 137:47-57. https://doi.org/10.1016/j.meatsci.2017.11.014.

Mancini, R. A., and M. C. Hunt. 2005. Current research in meat color. Meat Sci. 71:100-121. https://doi.org/10.1016/j. meatsci.2005.03.003.

Manissorn, J., S. Khamchun, A. Vinaiphat, and V. Thongboonkerd. 2016. Alpha-tubulin enhanced renal tubular cell proliferation and tissue repair but reduced cell death and cell-crystal adhesion. Sci. Rep.-UK. 6:28808. https://doi.org/10.1038/ srep28808.

Marino, R., M. Albenzio, A. della Malva, M. Caroprese, A. Santillo, and A. Sevi. 2014. Changes in meat quality traits and sarcoplasmic proteins during aging in three different cattle breeds. Meat Sci. 98:178-186. https://doi.org/10.1016/j. meatsci.2014.05.024.

Martin, D. N., and E. H. Baehrecke. 2004. Caspases function in autophagic programmed cell death in Drosophila. Development. 131:275-284. https://doi.org/10.1242/dev. 00933.

Matarneh, S. K., S. L. Silva, and D. E. Gerrard. 2021. New insights in muscle biology that alter meat quality. Annu. Rev. Anim. 
Biosci. 9:355-377. https://doi.org/10.1146/annurev-animal021419-083902.

McBryan, J., R. M. Hamill, G. Davey, P. Lawlor, and A. M. Mullen. 2010. Identification of suitable reference genes for gene expression analysis of pork meat quality and analysis of candidate genes associated with the trait drip loss. Meat Sci. 86:436-439. https://doi.org/10.1016/j.meatsci.2010.05.030.

McMillin, K. W. 2017. Advancements in meat packaging. Meat Sci. 132:153-162. https://doi.org/10.1016/j.meatsci.2017.04.015.

Moritz, C. P. 2017. Tubulin or not tubulin: heading toward total protein staining as loading control in western blots. PROTEOMICS. 17:1600189. https://doi.org/10.1002/pmic. 201600189.

Moritz, C. P., S. X. Marz, R. Reiss, T. Schulenborg, and E. Friauf. 2014. Epicocconone staining: A powerful loading control for western blots. PROTEOMICS. 14:162-168. https://doi.org/ 10.1002/pmic.201300089.

Nair, M. N., S. P. Suman, M. K. Chatli, S. Li, P. Joseph, C. M. Beach, and G. Rentfrow. 2016. Proteome basis for intramuscular variation in color stability of beef semimembranosus. Meat Sci. 113:9-16. https://doi.org/10.1016/j.meatsci.2015. 11.003 .

Naora, H., and H. Naora. 1995. Differential expression patterns of $\beta$-actin mRNA in cells undergoing apoptosis. Biochem. Bioph. Res. Co. 211:491-496. https://doi.org/10.1006/bbrc. 1995.1840.

Neethling, N. E., S. P. Suman, G. O. Sigge, L. C. Hoffman, and M. C. Hunt. 2017. Exogenous and endogenous factors influencing color of fresh meat from ungulates. Meat Muscle Biol. 1:253-275. https://doi.org/10.22175/mmb2017.06.0032.

Nolasco, S., J. Bellido, J. Gonçalves, J. C. Zabala, and H. Soares. 2005. Tubulin cofactor A gene silencing in mammalian cells induces changes in microtubule cytoskeleton, cell cycle arrest and cell death. FEBS Lett. 579:3515-3524. https://doi.org/10. 1016/j.febslet.2005.05.022.

Oliván, M., J. González, A. Bassols, F. Díaz, R. Carreras, E. Mainau, L. Arroyo, R. Peña, Y. Potes, A. Coto-Montes, K. Hollung, and A. Velarde. 2018. Effect of sex and RYR1 gene mutation on the muscle proteomic profile and main physiological biomarkers in pigs at slaughter. Meat Sci. 141:8190. https://doi.org/10.1016/j.meatsci.2018.03.018.

Ou, X.-M., C. A. Stockmeier, H. Y. Meltzer, J. C. Overholser, G. J. Jurjus, L. Dieter, K. Chen, D. Lu, C. Johnson, M. B. H. Youdim, M. C. Austin, J. Luo, A. Sawa, W. May, and J. C. Shih. 2010. A novel role for glyceraldehyde-3-phosphate dehydrogenase and monoamine oxidase $\mathrm{B}$ cascade in ethanol-induced cellular damage. Biol. Psychiat. 67:855-863. https://doi.org/10.1016/j.biopsych.2009.10.032.

Ouali, A., C. H. Herrera-Mendez, G. Coulis, S. Becila, A. Boudjellal, L. Aubry, and M. A. Sentandreu. 2006. Revisiting the conversion of muscle into meat and the underlying mechanisms. Meat Sci. 74:44-58. https://doi.org/10. 1016/j.meatsci.2006.05.010.

Patterson, B. M., A. C. Outhouse, E. T. Helm, L. Johnson, E. M. Steadham, J. C. M. Dekkers, K. J. Schwartz, N. K. Gabler, S. M. Lonergan, and E. Huff-Lonergan. 2021. Novel observations of peroxiredoxin-2 profile and protein oxidation in skeletal muscle from pigs of differing residual feed intake and health status. Meat Muscle Biol. 5:1-15. https://doi.org/10. 22175/mmb.12241.

Picard, B., and M. Gagaoua. 2020. Muscle fiber properties in cattle and their relationships with meat qualities: An overview. J. Agric. Food Chem. 68:6021-6039. https://doi.org/10.1021/ acs.jafc.0c02086.

Polati, R., M. Menini, E. Robotti, R. Millioni, E. Marengo, E. Novelli, S. Balzan, and D. Cecconi. 2012. Proteomic changes involved in tenderization of bovine Longissimus dorsi muscle during prolonged ageing. Food Chem. 135:2052-2069. https://doi.org/10.1016/j.foodchem.2012.06.093.

Racusen, D. 1973. Stoichiometry of the amido black reaction with proteins. Anal. Biochem. 52:96-101. https://doi.org/10.1016/ 0003-2697(73)90334-5.

Ramanathan, R., S. P. Suman, and C. Faustman. 2020. Biomolecular interactions governing fresh meat color in post-mortem skeletal muscle: A review. J. Agric. Food Chem. 68:12779-12787. https://doi.org/10.1021/acs.jafc.9b08098.

Rivero-Gutiérrez, B., A. Anzola, O. Martínez-Augustin, and F. S. de Medina. 2014. Stain-free detection as loading control alternative to Ponceau and housekeeping protein immunodetection in western blotting. Anal. Biochem. 467:1-3. https://doi.org/ 10.1016/j.ab.2014.08.027.

Romero-Calvo, I., B. Ocón, P. Martínez-Moya, M. D. Suárez, A. Zarzuelo, O. Martínez-Augustin, and F. S. de Medina. 2010. Reversible Ponceau staining as a loading control alternative to actin in western blots. Anal. Biochem. 401:318-320. https://doi.org/10.1016/j.ab.2010.02.036.

Ruan, W., and M. Lai. 2007. Actin, a reliable marker of internal control? Clin. Chim. Acta. 385:1-5. https://doi.org/10.1016/ j.cca.2007.07.003.

Saunders, P. A., E. Chalecka-Franaszek, and D.-M. Chuang. 1997. Subcellular distribution of glyceraldehyde-3-phosphate dehydrogenase in cerebellar granule cells undergoing cytosine arabinoside-induced apoptosis. J. Neurochem. 69:1820-1828. https://doi.org/10.1046/j.1471-4159.1997.69051820.x.

Sawa, A., A. A. Khan, L. D. Hester, and S. H. Snyder. 1997. Glyceraldehyde-3-phosphate dehydrogenase: Nuclear translocation participates in neuronal and nonneuronal cell death. P. Natl. Acad. Sci. USA. 94:11669-11674. https://doi.org/10. 1073/pnas.94.21.11669.

Sayd, T., C. Chambon, E. Laville, B. Lebret, H. Gilbert, and Ph. Gatellier. 2012. Early post-mortem sarcoplasmic proteome of porcine muscle related to lipid oxidation in aged and cooked meat. Food Chem. 135:2238-2244. https://doi.org/ 10.1016/j.foodchem.2012.07.079.

Sen, N., M. R. Hara, M. D. Kornberg, M. B. Cascio, B.-I. Bae, N. Shahani, B. Thomas, T. M. Dawson, V. L. Dawson, S. H. Snyder, and A. Sawa. 2008. Nitric oxide-induced nuclear GAPDH activates p300/CBP and mediates apoptosis. Nat. Cell Biol. 10:866-873. https://doi.org/10.1038/ncb1747.

Shackelford, S. D., T. L. Wheeler, M. K. Meade, J. O. Reagan, B. L. Byrnes, and M. Koohmaraie. 2001. Consumer impressions of Tender Select beef. J. Anim. Sci. 79:2605-2614. https://doi. org/10.2527/2001.79102605x.

Silva, L. H. P., R. T. S. Rodrigues, D. E. F. Assis, P. D. B. Benedeti, M. S. Duarte, and M. L. Chizzotti. 2019. Explaining meat quality of bulls and steers by differential proteome and 
phosphoproteome analysis of skeletal muscle. J. Proteomics. 199:51-66. https://doi.org/10.1016/j.jprot.2019.03.004.

Smith, P. K., R. I. Krohn, G. T. Hermanson, A. K. Mallia, F. H. Gartner, M. D. Provenzano, E. K. Fujimoto, N. M. Goeke, B. J. Olson, and D. C. Klenk. 1985. Measurement of protein using bicinchoninic acid. Anal. Biochem. 150:76-85. https:// doi.org/10.1016/0003-2697(85)90442-7.

Suman, S. P., and P. Joseph. 2013. Myoglobin chemistry and meat color. Annu. Rev. Food Sci. T. 4:79-99. https://doi.org/10. 1146/annurev-food-030212-182623.

Tang, H. L., A.-H. P. Le, and H. L. Lung. 2006. The increase in mitochondrial association with actin precedes Bax translocation in apoptosis. Biochem J. 396:1-5. https://doi.org/10. 1042/BJ20060241.

Tarze, A., A. Deniaud, M. Le Bras, E. Maillier, D. Molle, N. Larochette, N. Zamzami, G. Jan, G. Kroemer, and C. Brenner. 2007. GAPDH, a novel regulator of the pro-apoptotic mitochondrial membrane permeabilization. Oncogene. 26:2606-2620. https://doi.org/10.1038/sj.onc.1210074.

Taylor, S. C., T. Berkelman, G. Yadav, and M. Hammond. 2013. A defined methodology for reliable quantification of western blot data. Mol. Biotechnol. 55:217-226. https://doi.org/10. 1007/s12033-013-9672-6.

Taylor, S. C., and A. Posch. 2014. The design of a quantitative western blot experiment. BioMed Res. Int. 2014:361590. https://doi.org/10.1155/2014/361590.

Thacker, J. S., D. H. Yeung, W. R. Staines, and J. G. Mielke. 2016. Total protein or high-abundance protein: Which offers the best loading control for western blotting? Anal. Biochem. 496:7678. https://doi.org/10.1016/j.ab.2015.11.022.

Thangima Zannat, Mst., R. B. Bhattacharjee, and J. Bag. 2011. In the absence of cellular poly (A) binding protein, the glycolytic enzyme GAPDH translocated to the cell nucleus and activated the GAPDH mediated apoptotic pathway by enhancing acetylation and serine 46 phosphorylation of $\mathrm{p} 53$. Biochem. Bioph. Res. Co. 409:171-176. https://doi.org/10.1016/j.bbrc.2011. 04.094.

Towbin, H., T. Staehelin, and J. Gordon. 1979. Electrophoretic transfer of proteins from polyacrylamide gels to nitrocellulose sheets: Procedure and some applications. P. Natl. Acad. Sci. USA. 76:4350-4354. https://doi.org/10.1073/pnas.76.9.4350.

Tracy, C. M., A. J. Gray, J. Cuéllar, T. S. Shaw, A. C. Howlett, R. M. Taylor, J. T. Prince, N. G. Ahn, J. M. Valpuesta, and B. M. Willardson. 2014. Programmed cell death protein 5 interacts with the cytosolic chaperonin containing tailless complex polypeptide 1 (CCT) to regulate $\beta$-tubulin folding. J. Biol. Chem. 289:4490-4502. https://doi.org/10.1074/jbc.M113.542159.

Vigelsø, A., R. Dybboe, C. N. Hansen, F. Dela, J. W. Helge, and A. Guadalupe Grau. 2014. GAPDH and $\beta$-actin protein decreases with aging, making Stain-Free technology a superior loading control in western blotting of human skeletal muscle. J. Appl. Physiol. 118:386-394. https://doi.org/10.1152/japplphysiol. 00840.2014.

Wang, L.-L., L. Han, X.-L. Ma, Q.-L. Yu, and S.-N. Zhao. 2017. Effect of mitochondrial apoptotic activation through the mitochondrial membrane permeability transition pore on yak meat tenderness during postmortem aging. Food Chem. 234:323331. https://doi.org/10.1016/j.foodchem.2017.04.185.
Wang, P., and J.-C. Li. 2007. Trichosanthin-induced specific changes of cytoskeleton configuration were associated with the decreased expression level of actin and tubulin genes in apoptotic Hela cells. Life Sci. 81:1130-1140. https://doi. org/10.1016/j.lfs.2007.08.016.

Wang, T., J. Li, Y. Shao, W. Yao, J. Xia, Q. He, and F. Huang. 2020a. The effect of dietary garcinol supplementation on oxidative stability, muscle postmortem glycolysis and meat quality in pigs. Meat Sci. 161:107998. https://doi.org/10.1016/j. meatsci.2019.107998.

Wang, Y., R. Liu, Q. Hou, X. Tian, X. Fan, W. Zhang, and G. Zhou. 2020b. Comparison of activity, expression and S-nitrosylation of glycolytic enzymes between pale, soft and exudative and red, firm and non-exudative pork during post-mortem aging. Food Chem. 314:126203. https://doi.org/10.1016/j.foodchem.2020 .126203 .

Warner, R. D., P. L. Greenwood, D. W. Pethick, and D. M. Ferguson. 2010. Genetic and environmental effects on meat quality. Meat Sci. 86:171-183. https://doi.org/10.1016/j. meatsci.2010.04.042.

Welinder, C., and L. Ekblad. 2011. Coomassie staining as loading control in western blot analysis. J. Proteome Res. 10:1416 1419. https://doi.org/10.1021/pr1011476.

Xing, T., C. Wang, X. Zhao, C. Dai, G. Zhou, and X. Xu. 2017. Proteome analysis using isobaric tags for relative and absolute analysis quantitation (iTRAQ) reveals alterations in stress-induced dysfunctional chicken muscle. J. Agr. Food Chem. 65:2913-2922. https://doi.org/10.1021/acs. jafc.6b05835.

Yu, Q., X. Tian, L. Shao, L. Xu, R. Dai, and X. Li. 2018. Label-free proteomic strategy to compare the proteome differences between longissimus lumborum and psoas major muscles during early postmortem periods. Food Chem. 269:427-435. https://doi.org/10.1016/j.foodchem.2018.07.040.

Yu, Q., W. Wu, X. Tian, M. Hou, R. Dai, and X. Li. 2017. Unraveling proteome changes of Holstein beef $M$. semitendinosus and its relationship to meat discoloration during post-mortem storage analyzed by label-free mass spectrometry. J. Proteomics. 154:85-93. https://doi.org/10.1016/j.jprot.2016.12.012.

Zaboli, G., X. Huang, X. Feng, and D. U. Ahn. 2019. How can heat stress affect chicken meat quality? - A review. Poult. Sci. 98:1551-1556. https://doi.org/10.3382/ps/pey399.

Zapata, I., H. N. Zerby, and M. Wick. 2009. Functional proteomic analysis predicts beef tenderness and the tenderness differential. J. Agri. Food Chem. 57:4956-4963. https://doi.org/10. 1021/jf900041j.

Zhai, C., B. A. Djimsa, J. E. Prenni, D. R. Woerner, K. E. Belk, and M. N. Nair. 2020. Tandem mass tag labeling to characterize muscle-specific proteome changes in beef during early postmortem period. J. Proteomics. 222:103794. https://doi.org/ 10.1016/j.jprot.2020.103794.

Zhang, L., R. Liu, Y. Cheng, L. Xing, G. Zhou, and W. Zhang. 2019a. Effects of protein S-nitrosylation on the glycogen metabolism in postmortem pork. Food Chem. 272:613-618. https://doi.org/10.1016/j.foodchem.2018.08.103.

Zhang, L., X. Wang, J. Li, X. Zhu, F. Gao, and G. Zhou. 2017. Creatine monohydrate enhances energy status and reduces glycolysis via inhibition of AMPK pathway in pectoralis major muscle of transport-stressed broilers. J. Agri. Food 
Chem. 65:6991-6999. https://doi.org/10.1021/acs.jafc. $7 \mathrm{~b} 02740$.

Zhang, M., D. Wang, X. Xu, and W. Xu. 2019b. Comparative proteomic analysis of proteins associated with water holding capacity in goose muscles. Food Res. Int. 116:354-361. https://doi.org/10.1016/j.foodres.2018.08.048.

Zhang, Y., Y. Mao, K. Li, X. Luo, and D. L. Hopkins. 2019c. Effect of carcass chilling on the palatability traits and safety of fresh red meat. Compr. Rev. Food Sci. F. 18:1676-1704. https:// doi.org/10.1111/1541-4337.12497.
Zhao, J., L. Bowman, X. Zhang, X. Shi, B. Jiang, V. Castranova, and M. Ding. 2009. Metallic nickel nano- and fine particles induce JB6 cell apoptosis through a caspase-8/AIF mediated cytochrome c-independent pathway. J. Nanobiotechnol. 7:2. https://doi.org/10.1186/1477-3155-7-2.

Zuo, H., L. Han, Q. Yu, K. Niu, S. Zhao, and H. Shi. 2016. Proteome changes on water-holding capacity of yak longissimus lumborum during postmortem aging. Meat Sci. 121:409419. https://doi.org/10.1016/j.meatsci.2016.07.010. 